\title{
KESANTUNAN BERBAHASA GURU DAN SISWA DALAM PEMBELAJARAN BAHASA INDONESIA PADA KELAS VII SMP NEGERI 1 KUTA UTARA
}

\author{
Ni Luh Putu Budi Pradnyani ${ }^{1}$, I Ketut Darma Laksana ${ }^{2}$, I Nyoman Aryawibawa ${ }^{3}$ \\ 1,2,3 Fakultas IImu Budaya, Universitas Udayana \\ e-mail: boedipradnyani@gmail.com
}

\begin{abstract}
Abstrak
Penelitian ini bertujuan mendeskripsikan bentuk tingkat kesantunan berbahasa guru dan siswa dalam pembelajaran bahasa Indonesia kelas VII di SMP Negeri 1 Kuta Utara. Jenis penelitian yaitu deskriptif kualitatif. Data dalam penelitian ini berupa katakata maupun kalimat yang mengandung pematuhan prinsip kesantunan dan pelanggaran prinsip kesantunan berbahasa guru dan siswa. Teknik pengumpulan data melalui teknik simak, teknik catat, wawancara, dan observasi langsung. Hasil penelitian menunjukkan bahwa peneliti menemukan 18 data yang mengandung 5 pematuhan prinsip kesantunan. Berdasarkan hasil analisis mengenai tingkat pematuhan kesantunan berbahasa guru dan siswa dalam pembelajaran bahasa Indonesia pada kelas VII di SMP Negeri 1 Kuta Utara dapat dikatakan guru lebih santun dalam penggunaan bahasa, karena jumlah pematuhan prinsip kesantunan berbahasa guru lebih banyak dibanding tingkat kesantunan berbahasa pada siswa terutama pada maksim penghargaan dimana guru lebih banyak menerapkan maksim ini untuk membangkitkan semangat belajar pada siswa.
\end{abstract}

Kata kunci : prinsip kesantunan berbahasa, maksim

\begin{abstract}
This study aims to describe the teacher's and students' language behavioral level in learning Indonesian class VII in Kuta Utara 1 Junior High School. This type of research is qualitative descriptive. The data in this study are in the form of words and sentences that contain adherence to politeness principles and violations of the teacher and student politeness principles. Data collection techniques in this study used listening techniques, note-taking techniques, interviews, and direct observation. The results showed that the researchers found 18 data of 5 forms politeness Based on the analysis of the level of politeness of the teacher and students in Indonesian language learning at grade VII in Kuta Utara 1 Junior High School that teacher are more polite in the use of languagebecause the number of termination principles of teacher politeness is high maximally reward where more teachers impose this maxim to encourage enthusiasm study with students.
\end{abstract}

Keywords : The principle of politeness is challenging, maxim. 


\section{PENDAHULUAN}

Bahasa adalah alat komunikasi yang berupa bentuk sistem simbol suara yang di hasilkan oleh manusia dan sebagai alat untuk berinteraksi dengan lingkungan di sekitar kita. Tanpa bahasa kita tidak dapat berinteraksi satu sama lain karena bahasa merupakan sumber untuk terciptanya interaksi manusia dengan orang lain yang juga merupakan simbol dari suatu bangsa atau suku dan menjadi salah satu ciri khas bangsa atau suku sehingga orang-orang dapat mengenali bangsa atau suku lewat bahasa mereka. Bahasa di dunia sangat banyak dan tidak sepenuhnya pengucapannya sama. Bahasa dapat dikatakan sebagai jembatan antara orang-orang untuk berkomunikasi dengan orang lain.

Santun berbahasa dapat dipandang sebagai usaha untuk menghindari konflik antara penutur dengan mitra tutur. Dalam hal ini, kesantunan berbahasa merupakan cerminan budaya suatu masyarakat. Dalam sebuah masyarakat, selalu ada hierarki sosial yang dikenakan pada kelompok-kelompok anggota mereka. Selain itu, faktor konteks juga menyebabkan kesantunan berbahasa perlu diterapkan. Suasana formal atau resmi sangat menekankan kesantunan bahasa tersebut. Kesantunan berbahasa sebenarnya merupakan cara yang ditempuh oleh penutur di dalam berkomunikasi agar mitra tutur tidak merasa tertekan, tersudut ataupun tersinggung (Markhamah, dkk., 2009:153). Menurut Brown dan Levinson (1987), kesantunan berbahasa dimaknai sebagai usaha penutur untuk menjaga harga diri atau wajah, baik pembicara maupun pendengar. Geoffrey Leech (1983) menyatakan bahwa kesantunan berbahasa itu tidak mengenal budaya barat ataupun timur, meskipun terdapat perbedaan di antara keduanya. Kesantunan berbahasa dalam pembelajaran di sekolah sangatlah penting. Kesantunan berbahasa menjadi salah satu aspek kebahasaan yang dapat mengembangkan atau meningkatkan kecerdasan emosional para penuturnya. Kesantunan berbahasa juga sebagai kespoanan dalam menggunakan bahasa baik secara lisan maupun tulisan. Aktivitas berkomunikasi dalam pembelajaran dapat dilakukan dengan cara penggunaaan bahasa yang sopan dan santun baik dalam situasi formal maupun nonformal.

Dalam penelitian ini, peneliti membahas tentang bentuk pematuhan dan pelanggaran kesantunan berbahasa siswa dalam pembelajaran Bahasa Indonesia serta kaitannya dengan pembelajaran di Sekolah
Menengah Pertama. Adapun penemuan dalam penelitian ini berupa pematuhan terhadap prinsip kesantunan berbahasa yang mengacu pada pendapat. Berikut hasil penelitian yang ditemukan.

\section{METODE}

Jenis penelitian yang digunakan dalam penelitian ini adalah penelitian kualitatif. Menurut Tohirin (2013: 3) penelitian kualitatif merupakan penelitian yang memahami berbagai fenomena yang dialami oleh subjek penelitian dan dapat dideskripsikan menggunakan kata-kata. Sedangkan penelitian deskriptif adalah penelitian yang dimaksudkan untuk menyelidiki keadaan, kondisi, atau hal-hal lain yang sudah disebutkan yang hasilnya dipaparkan dalam bentuk laporan penelitian (Arikunto, 2010:3). Data penelitian yang digunakan berupa tuturan siswa dalam kelas Bahasa Indonesia. Sumber data merupakan tuturan siswa dalam interaksi kelas di SMP Negeri 1 Kuta Utara. Teknik pengumpulan data melalui teknik simak, teknik catat, wawancara, dan observasi langsung. Teknik simak digunakan untuk memperoleh data melalui menyimak bahasa (Mahsun, 2012: 92). Berdasarkan pemaparan di atas, penelitian ini memaparkan beberapa hal berkaitan dengan kajian pragmatik khususnya kesantunan berbahasa, yaitu pematuhan dan pelanggaran kesantunan berbahasa siswa dalam konteks pembelajaran dan kaitannya dengan materi teks berita di Sekolah Menengah Pertama (SMP).

\section{HASIL DAN PEMBAHASAN}

Penelitian ini membahas tentang bentuk pematuhan dan pelanggaran kesantunan berbahasa siswa dalam pembelajaran Bahasa Indonesia serta kaitannya dengan pembelajaran materi teks berita di Sekolah Menengah Pertama. Adapun penemuan dalam penelitian ini berupa pematuhan terhadap prinsip kesantunan berbahasa yang mengacu pada pendapat. Berikut hasil penelitian yang ditemukan.

\section{Tingkat Kesantunan Berbahasa Guru dan Siswa dalam Pembelajaran Bahasa Indonesia di SMP Negeri 1 Kuta Utara}

Bentuk Pematuhan Prinsip Kesantunan Berbahasa:

\section{Maksim Kebijaksanaan}

Maksim kebijaksanaan ini menuntut penutur untuk bersikap bijak dalam 
berkomunikasi. Penutur hendaknya meminimalkan kerugian dan memaksimalkan keuntungan orang lain. Dalam maksim kebijaksanaan tuturan dapat dikatakan lebih santun jika diungkapkan dengan kalimat tidak langsung

\section{Data 1}

S 9 : "Mang, masih paketan hotspotmu?"

S 11 : "kenapa? Masih aku koneksikan ke laptop."

S 9 : "kamu koneksiin nanti aja lagi Mang. Kel abe hp ne pesu kesisi" (Mau tak bawa hpnya keluar).

S 11 : "Lhoo terus aku kan masih pake Gung?"

S 9 : "Tak bawa sebentar aja mau koneksiin ke hpnya Putra, urgensi katanya." menit"

S11 : "Balikin ya. Maksimal 5

S 9 : "Inggih mbok... tenang aja."

Konteks : Percakapan terjadi di dalam kelas disaat Guru memberikan tugas untuk mencari contoh teks berita di internet dan wifi sekolah ternyata bermasalah, S 9 (penutur) ingin meminjam handphone untuk dikoneksikan ke handphone Putra kepada S 11 (mitra tutur).

\section{Analisis}

Tuturan siswa di atas memenuhi prinsip kesantunan dengan maksim kebijaksanaan. Hal ini terlihat dari jawaban siswa S11 yang dapat memahami akan perlunya hotspot yang didapatkan dalam menjelajahi informasi dengan internetdn mencari materi yang disampaikan guru. Sehingga percakapan diatas memenuhi maksim kebijaksanaan, dimana penutur dapat memaksimalkan keuntungan bagi mitra tutur. Penutur dapat memberikan hotspot atau paket internet yang dibutuhkan mitra tutur.

\section{Maksim Penghargaan}

Seseorang bisa dianggap santun jika dalam komunikasi bertutur berusaha untuk memberikan pernghargaan terhadap pihak lain. Pada maksim ini, diharapkan penutur dan mitra tutur tidak saling mengejek, tidak saling mencela, tidak saling membenci, dan tidak saling merendahkan pihak lawan bicara. Penutur yang mengejek peserta tutur lain saat kegiatan bertutur dapat dikatakan sebagai orang yang tidak sopan. Dikatakan seperti itu, karena mengejek merupakan tindakan tidak menghargai orang lain.

\section{Data 1}

$\mathrm{G}$ : nah setelah itu apa?

S 5 : kalimat pembuka pada paragraph pertama

G : ya, betul sekali anak-anak, kalian semuanya sudah mengerti betul bagianbagian teks berita.

\section{Analisis}

Tuturan guru di atas menuhi prinsip kesantunan dengan maksim penghargaan. Hal ini terlihat dari tuturan guru yang berusaha memberikan penghargaan kepada siswa dengan dialog "kalian semuanya sudah mengerti betul bagian-bagian teks berita". Dialog tersebut menjelaskan bahwa guru mengapresiasi jawaban siswa ketika siswa berusaha untuk menjawab pertanyaan dari guru.

\section{Data 2}

G : "Ini temanya apa anak-anak?"

S3: "Kalau menurut saya ini temanya tentang berita kejahatan atau kriminal bu. Jadi bisa dilihat di paragraph pertamanya lokasinya berada di kantor polisi."

G : "Weeiss mantap...Luar biasa jawabanmu nak ."

Konteks : Percakapan terjadi dalam kegiatan diskusi kelompok. S3 memberikan usulan terkait jawaban dan disetujui disertai sanjungan oleh guru.

\section{Analisis}

Pematuhan maksim penghargaan dapat dilihat pada data 2 di atas. Ungkapan "luar biasa" menunjukkan pematuhan maksim penghargaan sebab memberi pujian dan merasa kagum terhadap jawaban mitra tutur.

\section{Maksim Pemufakatan}

Maksim permufakatan bisa disebut maksim kecocokan. Pada maksim ini, menekankan supaya si penutur dan mitra tutur dapat saling membina kecocokan, persetujuan atau kemufakatan di dalam kegiatan bertutur. Penutur dan mitra tutur dapat dikatakan memiliki sikap yang santun jika sudah terjadi kemufakatan atau kecocokan dalam kegiatan bertutur.

\section{Data}

G : jika kalian semua sudah pandai menulis teks berita maka bisa 
menjadi bekal kalian nanti dalam menulis teks lainnya seperti menulis laporan. Sudah paham manfaatnya?

\section{S : sudah bu...}

Guru : baik kita lanjut berikutnya. Jika menurut kalian materinya penting maka anakanak harus menulis di buku catatan masingmasing ya

\section{S : (melakukan perintah guru)}

Konteks : Percakapan terjadi ketika guru memberikan penjelasan terkait dengan manfaat yang didapat jika mempelajari teks berita dan unsur-unsurnya.

\section{Analisis}

Tuturan siswa di atas memenuhi prinsip kesantunan berbahasa dengan maksim pemufakatan. Hal ini terlihat dari tuturan antara guru dan siswa yang memiliki pemufakatan atau persetujuan bahwa siswa sudah paham akan menulis surat pribadi dan guru melanjutkan materi berikutnya dengan persetujuan siswa.

\section{Maksim Kesederhanaan}

Maksim kesederhanaan dapat disebut maksim kerendahan hati, dalam komunikasi peserta tutur diharapkan dapat memiliki sikap kerendahan hati dengan cara mengurangi pujian atas dirinya sendiri. Orang bisa dikatakan sombong hati jika dalam komunikasi bertutur selalu mengunggulkan dirinya sendiri atau memuji dirinya sendiri. Di kehidupan masyarakat Indonesia, kesederhanaan atau kerendahan hati dijadikan sebagai parameter penilaian kesantunan seseorang. Sebagai contoh tuturan di bawah ini sering terjadi dalam kehidupan bermasyarakat.

\section{Data}

Guru : "ayo maju ke depan."

S8: “ (maju ke depan) ini gimana bu? Kalau salah tolongdibenarkan ya bu."

Analisis

Data diatas menjelaskan bahwa $S 8$ mematuhi maksim kesederhanaan yang diungkapkan dalam kalimat "kalau salah tolong dibenarkan ya bu". Ungkapan tersebut berarti bahwa mematuhi maksim kesederhanaanmerendah dengan diri. Tuturan siswa di atas memenuhi prinsip kesantunan berbahasa dengan maksim kesederhanaan. Tuturan siswa di atas berusaha merendahkan diri sendiridengan menanyakan suatu hal kepada guru dan meminta tolong kepada guru untuk dibenarkan jawaban yang salah.

\section{Maksim Kesimpatian}

Dalam maksim kesimpatian, diharapkan peserta tutur dapatmemaksimalkan sikap simpati kepada orang lain. Tuturan akan dianggapsantun apabila penutur dapat menunjukkan sikap simpatik terhadap oranglain dan menghindari sikap sinis maupun antipati. Adapun dapat dilihatseperti data berikut.

\section{Data 5}

G : :Yuk selanjutnya. Bayu maju nak."

S 6 : "Dalam kesempatan ini saya akan menjelaskan beberapa unsur-unsur yang terdapat dalam teks berita.

S 12 : "Yeee..Pak Ketua .. semangat."

S 6 : (tersenyum) "Kelompok kami menjawab..." (menjelaskan unsur-unsur teks berita)

S12 : "Tepuk tangan gaes."

S 6 : "Makasih semuanya"

Konteks : Interaksi terjadi saat salah seorang siswa menjelaskan hasil diskusi ke depan kelas. Siswa secara bergiliran maju untuk menjelaskan hasil diskusi kelompoknya.

Analisis

Data di atas merupakan bentuk pematuhan prinsip kesantunan yakni maksim kesimpatian. Dikatakan demikian, sebab dalam percakapan S 6 saat maju kemudian diberi motivasi dan semangat oleh $S 12$ yang merupakan temannya. Ungkapan berupa "semangat"menunjukkan sikap simpati terhadap orang lain.

\section{Pelanggaran Kesantunan Berbahasa dalam Pembelajaran Bahasa Indonesia}

Bentuk Pelanggaran Prisnsip Kesantunan Berbahasa Guru dan Siswa Dalam Pembelajaran Bahasa Indonesia di SMP Negeri 1 Kuta Utara.

Bentuk pelanggaran prinsip kesantunan berbahasa siswa dan guru dalam pembelajaran Bahasa Indonesia dijabarkan pada bagian berikut. Deskripsi pelanggaran prinsip kesantunan berbahasa dibahas sesuai dengan maksim yang dilanggar. 


\section{Maksim Kebijaksanaan}

Maksim kebijaksanaan menuntut sebuah tuturan supaya tidakmemberatkan lawan tutur dan dirasa lebih halus. Seseorang dalam bertutur harus memiliki sikap arif. Pelanggaran terhadap maksim ini ditandai dengan penutur yang menggunakan diksi yang kasar, memerintah atau menegur secara langsung, memberi saran secara langsung, menolak dengan intonasi tinggi, dan kasar. Penyimpangan maksim kebijaksanaan dapat dilihat pada data berikut.

Data

G : "Ayo yang di pojok pura-pura tidak dengar, Bunter maju Ter."

S 2 : "We..maju sana."

S 19 : "La aku udah lho, nomor 5ciri-ciri teks berita."

S2 : "Yaa maju aja lagi belum lengkap kok."

S 19 : "Gantianlah."

Konteks : Interaksi terjadi saat pelajaran Bahasa Indonesia dengan materi teks berita. Siswa diminta guru untuk maju menuliskan materi secara bergiliran.

\section{Analisis}

Tuturan dari data diatas menyebutkan bahwa guru menyebut nama siswa dengan nama bukan sebenarnya. Hal tersebut tampak pada ungkapan "Bunter". Siswa yang diminta maju tersebut sempat tampak tidak mendengar.Siswa 2 (S2) yang sudah maju menulis materi memerintah $\mathrm{S} 19$ yang tadi tampak tidak mendengarkan instruksi. Walaupun sebenarnya S19 sudah maju. Namun, tuturan yang disampaikan S2 tersebut terdengar kurang santun dengan ungkapan "maju sana" yang artinya segera maju. Tuturan tersebut disampaikan penutur dengan memerintah secara langsung dan tampak ada paksaan kepada mitra tutur. Paksaan tersebut dipertegas dengan kata "Yaa maju aja lagi belum lengkap kok". Tuturan tersebut juga melanggar skalaketidaklangsungan sebab terdapat unsur paksaan dan sikap perintah.

\section{Pelanggaran Maksim Penghargaan \\ Maksim penghargaan menuntut tiap peserta}

tuturanmemaksimalkankerugianbagidirinyasen diridanmeminimalkan keuntungan diri sendiri. Pelanggaran maksim penghargaan ini dapat ditandai dengan memberi kritik yang menjatuhkan orang lain, berbicara namun menyakiti hati orang lain, tidak berterima kasih saat mendapat bantuan/saran,tidak menghargai orang lain, dan mementingkan kepentingan diri.

\section{Data}

S 14 : "He, Can. Tulisan ape ne? Cenik bin kuang cenik to." (Tulisan apa ini? Kecilin lagi kurang kecil itu)

S11 : "Engken emangne? Neh tulis pedidi." (Kenapa memangnya? Nih tulis sendiri).

Konteks : Percakapan terjadi saat siswa menulis materi di papan tulis. Namun, S 14 menulis dengan tulisan yang kurang jelas atau kurang besar sehingga susah dibaca.

\section{Analisis}

Data diatas menunjukkan adanya pelanggaran maksim pujian atau penghargaan terhadap orang lain. Tampak pada tuturan yang disampaikan S 14 dengan kalimat "He, Can. Tulisan ape ne? Cenik bin kuang cenik to." Kalimat tersebut merupakan bentuk sindiran halus atau ironi. S 14 mengutarakan kalimat dengan kata yang bertentangan dengan makna yang sebenarnya. Respons $\mathrm{S}$ 11 juga melanggar skala ketidaklangsungan sebab menyuruh secara langsung kepada lawan tutur. S 14 mencela tulisan S 11 yang pada dasarnya merupakan bentuk ungkapan yang menyakiti hati orang lain dan tidak menghargai orang lain. Dengan demikian, kedua pihak melanggar maksim penghargaan.

\section{PENUTUP}

Kesantunan berbahasa siswa akan tampak saat menjalin interaksi dengan siswa lain maupun dengan guru baik dalam konteks pembelajaran maupun di luar konteks pembelajaran. Berdasarkan hasil pembahasan, disimpulkan bahwa kesantunan berbahasa siswa lebih banyak mematuhi prinsip kesantunan berbahasa menurut Leech yakni maksim kebijaksanaan, maksim kesederhanaan, maksim permufakatan, maksim penghargaan, dan maksim kesimpatian.Peneliti menemukan 18 data yang mengandung 5 pematuhan prinsip kesantunan berbahasa pada guru dan siswa dalam pembelajaran Bahasa Indonesia yang terdiri dari maksim kebijaksanaan 1 data, maksim kesederhanaan 3 data, maksim pemufakatan 3 data, maksim penghargaan 4 data, maksim kesederhanaan 3 data, maksim pemufakatan 1 data, dan maksim kesimpatian 3 data. 
Selanjutnya terdapat Peneliti menemukan 2 data yang mengandung 2 bentuk pelanggaran prinsip kesantunan berbahasa pada guru dan siswa dalam pembelajaran Bahasa Indonesia yang terdiri dari dua jenis maksim kesantunan berbahasa, yaitu maksim kebijaksanaan 1 data, maksim penghargaan 1 data. Berdasarkan hasil analisis mengenai tingkat pematuhan kesantunan berbahasa guru dan siswa dalam pembelajaran bahasa Indonesia pada kelas VII di SMP Negeri 1 Kuta Utara dapat dikatakan guru lebih santun dalam penggunaan bahasa, karena jumlah pematuhan prinsip kesantunan berbahasa guru lebih banyak dibanding tingkat kesantunan berbahasa pada siswa terutama pada maksim penghargaan dimana guru lebih banyak menerapkan maksim ini untuk membangkitkan semangat belajar pada siswa.

\section{DAFTAR PUSTAKA}

Bogdan, Robert dan Steven J. Taylor. 1992. Pengantar Metoda PenelitianKualitatif (ed: Arief Furchan). Surabaya: Usaha Nasional.

Brown, P. and Levinson, S. 1987. Politeness: Some Universals in Language usage. Press Cambridge: Cambridge University

Chaer, Abdul dan Leonie Agustina. 2004. Sosiolinguistik: Perkenalan Awal.Jakarta: Rineka Cipta.

Chaer, Abdul. 2010. Sintaksis Bahasa Indonesia (Pendekatan Proses). Jakarta: Rineka Cipta.

Leech, Geoffrey. 2011. Prinsip-prinsip Press. Pragmatik (terj. Oka). Jakarta: UI

Miles, Mattew B. dan A. Michael Huberman. 2007. Analisis Data Kualitatif:

Buku Sumber Metode-metode Baru. Jakarta: UI Press.

Pranowo. 2009. Bahasa Berbahasa Secara Santun. Yogyakarta: Pustaka Pelajar.

Rahardi, Kunjana. 2009. Pragmatik: Imperatif Bahasa Indonesia. Erlangga: Jakarta.

Wijana, I Dewa Putu dan Muhammad Rohmadi. $2011 . \quad$ Analisis WacanaPragmatik. Surakarta: Yuma Pustaka. 